\title{
Sistemas agrários na Velha Província: O processo de transição para o trabalho livre sob o signo da Modernização Conservadora (1850-1888)
}

\author{
Daniel de Pinho Barreiros
}

\section{A modernização conservadora no Brasil}

O processo estrutural de dissolução do escravismo não teve como consequência a instauração de relações de trabalho capitalistas no campo, nem tampouco deu origem à uma economia agrícola formada hegemonicamente por proprietários rurais de pequeno e médio porte. A composição social do conjunto de atores envolvidos na luta política pela superação do escravismo foi fator importante para que os resultados do processo tenham sido muito distantes daqueles obtidos pela burguesia industrial norteamericana em sua luta contra o trabalho escravo. No Brasil, as condições de surgimento de uma classe burguesa fora da influência do capital comercial e da agroexportação, e com força suficiente para oferecer uma ameaça concreta à "velha sociedade", não se apresentaram. As camadas médias urbanas, entre devaneios liberais e adesões ao sistema, não ofereceram resistência efetiva. Mais ainda, o próprio capital industrial ficara subordinado ao comercial, fosse pela atuação direta do plantador-negociante na atividade industrial, ou pela ligação da fraca burguesia industrial imigrante ao funcionamento e interesses da agroexportação. O Estado tornara-se parceiro - e instrumento - das classes proprietárias rurais na transição para o capitalismo, preservando a grande propriedade e sua hegemonia.

Assim, o advento do trabalho livre na província fluminense foi marcado pelo signo da "via prussiana” de transição para o capitalismo, tal como conceituou Barrington Moore Jr. (BARREIROS, 2002). A "modernização conservadora" consistiu da construção de bases para uma sociedade urbano-industrial articulada à preservação da antiga estrutura de propriedade e trabalho no campo. Isto significa que a industrialização e a urbanização avançaram com base em uma economia agrícola comercial fundamentada em um "sistema repressivo de mão-de-obra", onde o trabalhador era submetido ao proprietário não através do mercado, mas por meio de coerção extraeconômica. O esgotamento do escravismo não teve como resultado a eliminação do latifúndio e o predomínio econômico do farmer, tal como nos Estados Unidos, e nem a formação de relações de trabalho capitalistas, com operários rurais plenamente expropriados. O latifúndio permaneceu, explorando mão-de-obra em regimes de trabalho não-capitalistas os mais diversos, e nas franjas do sistema formou-se uma economia agrária de posseiros integrados ou não aos mercados urbanos de gêneros alimentícios.

Mas a modernização conservadora não foi somente obra de um projeto classista hegemônico. As condições estruturais impuseram limites às opções dos atores históricos. As relações entre os diferentes sistemas agrários existentes à época da dissolução do escravismo foram fator crucial na preservação de relações de trabalho "repressivas" após a Abolição, em completa simbiose com o alvorecer do capitalismo industrial urbano, conformando a "via prussiana" de transição para o capitalismo.

Privilegiamos nesta análise trabalhos referentes à província do Rio de Janeiro por alguns fatores em especial. A abundância com que foram produzidos durante um determinado período de nossa história acadêmica foi um primeiro fator. É possível observar uma verdadeira "divisão de trabalho" no que compete à análise de diferentes localidades na província, tendo os historiadores abraçado - com perspectivas convergentes, ainda que diversas - diferentes municípios em trabalhos monográficos, ricos em detalhes e perspectivas teóricas. Em segundo lugar, tendo sido o Rio de Janeiro palco de uma retração econômica ao fim do século XIX, nos interessa em especial saber de que forma as diferentes classes reagiram a este desafio. É, desta forma, uma região em crise que nos interessa para medirmos o limite das transformações sociais no 
campo decorrentes de 1888. Pretenderemos mostrar que, quando integrados, estes estudos monográficos podem oferecer um panorama detalhado dos rumos da modernização conservadora na "Velha Província".

Buscamos caracterizar os sistemas agrários fluminenses a partir: a) da evolução dos tipos de cultura praticados; b) do direcionamento da produção e do grau de inserção mercantil da mesma (mercados internos, externos, subsistência); c) da relação entre condições técnicas, aplicação de capital e fronteira agrícola; d) da relação entre o capital comercial e o produtor direto; e) dos rumos tomados pela propriedade da terra e pelas relaçôes de trabalho após 1888 (perda de autonomia de pequenos lavradores, "caipirização", colonato, meação, proletarização etc.). A partir destes elementos, quatro modelos de sistemas agrários foram identificados: a)fronteira agrícola fechada e concentração fundiária; b)fronteira agrícola aberta e concentração fundiária; c)fronteira agrícola e concentração variadas; d)fronteira agrícola aberta e desconcentração fundiária. Com base no mosaico formado pelas relações entre os sistemas agrários identificados, criticaremos a existência concreta do primeiro modelo (fronteira fechada e concentração fundiária), e a partir desta análise, verificamos a presença de condições estruturais para a modernização conservadora.

\section{Alguns modelos de sistemas agrários}

\subsection{Fronteira agrícola fechada e concentração fundiária}

Márcia M. Motta (MOTTA, 1989) dedicou-se ao estudo do processo de construção e remodelamento social de uma região considerada "de fronteira agrícola fechada", o antigo município de Niterói, entre 1808 e 1888. Partiremos deste ponto como exemplo inicial para a compreensão dos rumos da formação agrária pós-1888, considerando-o como caso atípico no conjunto dos demais estudos relativos ao universo rural fluminense, bem como de outras províncias. Ainda assim, pretendemos relativizar este mesmo caráter singular propondo alguns elementos que podem vir a contribuir para a reinterpretação de certas conclusões da autora, a partir da leitura do citado trabalho em conjunto com outros trabalhos na mesma área.

A proximidade de Niterói com o mercado urbano da cidade do Rio de Janeiro foi um elemento de importância na caracterização do sistema agrário da região, e principalmente, de seus rumos posteriores à ruptura do escravismo. A redefinição do papel deste núcleo urbano com o processo de "interiorização da metrópole", desde 1808, e com a emancipação política, conduziram ao acirramento da urbanização e ao aumento demográfico. A transformação da cidade numa "região nodal" fez com que se tornasse um polo de irradiação de transformações na área em seu entorno. Tal processo também engendrou um aumento de preços dos alimentícios, gerando uma situação de instabilidade no abastecimento deste centro, que é atribuída às decisões dos controladores dos meios de produção e do serviço de comercialização destes produtos (MOTTA, 1989: 36-38).

A atividade canavieira entrou em um processo de crise na região por volta de princípios do século XIX, ocasionada por uma perda de dinamismo em função do desgaste do solo e pela migração desta atividade para áreas mais novas. O cultivo de alimentos, presente pelo menos desde o fim do século XVIII, mesmo não tendo tido grande expressividade, criava uma primeira base de apoio para uma transformação nos objetivos da produção agrícola. A nova etapa de urbanização da cidade do Rio de Janeiro teria atuado em termos de demanda como um catalisador, engendrando uma resposta expressa na expansão da oferta de alimentos e na transformação de parte substancial das áreas dedicadas à cana-de-açúcar em policultura de gêneros para a sustentação do consumo urbano (MOTTA, 1989: 45).

A proximidade do mercado consumidor e a fronteira agrícola fechada, reduzindo a possibilidade de expansão através do modo "arcaico" levaram, segundo Motta, à definição da produção de frutas e legumes em Niterói a partir de um caráter intensivo. O papel do monopólio da terra na sociedade local ganhava importância, portanto, mesmo num momento anterior à absolutização da propriedade privada da terra, ou seja, da sua transformação em capital (MOTTA, 1989: 53-55). ${ }^{1}$ Relacionando densidade demográfica e suprimento de terras, afirma a autora o papel da pressão do amplo contingente de homens livres na re- 
gião em contraste com a quantidade de terras disponíveis, configurando uma situação de fronteira fechada típica: mão-de-obra abundante e monopólio fundiário. A existência de pântanos e terrenos inadequados para a agricultura em $50 \%$ de sua extensão, até meados do século XX, fez com que o quadro de concentração ainda fosse mais agravado. Os pedidos de sesmarias na região apontavam a preocupação dos proprietários em, antes de manter as fronteiras de suas fazendas aptas à expansão, confirmar a posse da terra diante da pressão exercida pela massa de homens livres sem-terras (MOTTA, 1989: 56-59).

Diante do exposto, podemos indicar quatro pontos fundamentais para a caracterização do primeiro modelo, a partir dos dados fornecidos por Motta: a) Niterói constitui-se em região de ocupação antiga; b) teve sua economia agrícola baseada, a partir de um determinado momento, na produção de alimentos para mercados urbanos; c) teve uma atividade agroexportadora inicial, mas desarticulada pelo desgaste do solo; d) teve na produção de alimentos uma alternativa à decadência. O município de Niterói consistiria, portanto, num primeiro modelo teórico de estrutura sócioprodutiva agrária no Brasil do século XIX: fronteira agrícola fechada e densidade demográfica suficiente para configurar uma situação de submissão da mão-de-obra livre e produção em caráter intensivo. ${ }^{2}$

\subsection{Fronteira agrícola aberta e concentração fundiária}

Em Paraíba do Sul, a relação entre quantidade de terras disponíveis para a agricultura, o nível técnico empregado no cultivo e as relações de trabalho apresentaram um caráter distinto daquele verificado por Motta no município de Niterói. João Fragoso (FRAGOSO, 1983) demonstrou como a baixa densidade demográfica e a existência de matas virgens disponíveis conduziram à configuração de um sistema de exploração do solo baseado em uma dinâmica extensiva, com técnicas, capitais e instrumentos desempenhando papel diminuto na reprodução do sistema, quase que baseada inteiramente na ocupação da terra e na exploração da mão-de-obra. Ao contrário da agricultura europeia dos séculos XVIII e XIX, onde era comum o sistema de pousio associado à atividade pecuária (produzindo adubo e força motriz) e a revitalização do solo por meio de aplicação de trabalho, o sistema produtivo agrário em Paraíba do Sul (e facilmente generalizável para a maior parte da agricultura nacional no século XIX) não parece ter baseado a sua reprodução nestes expedientes.

A agricultura de alimentos - fosse ela por parte de pequenos lavradores independentes ou no interior das plantations "monocultoras" - fundava-se no uso predatório da terra e das matas virgens, fertilizando-se o solo por meio de queimadas e evitando-se o maior dispêndio de capital e trabalho. A abundância de solos férteis e intocados permitia que se explorasse toda uma região até a sua exaustão e dali migrar para outra ainda na plenitude de sua fertilidade. É desnecessário dizer que tal prática eliminava impulsos para o uso e desenvolvimento de técnicas de recuperação e fertilização do solo. Portanto, uma fronteira agrícola aberta e matas virgens levavam os lavradores a perpetuarem suas culturas por meio de práticas com alto grau de devastação e desequilíbrio ambiental (FRAGOSO, 1983: 15-19).

As enxadas e as cavadeiras eram os instrumentos de trabalho habituais, sendo o uso do arado difícil pela irregularidade dos terrenos em Paraíba do Sul. A prática de queimadas criava também uma "topografia" acidentada, onde pedras e restos de árvores impediriam a passagem de arados para revolver a terra. Da mesma forma, gerava uma separação improfícua entre pecuária e agricultura, desestimulando ainda mais a prática da adubação natural.

Em outras palavras, o baixo nível das forças produtivas presente nesta forma de produção dá origem, de um lado, a uma agricultura extensiva e, de outro, a uma pecuária igualmente extensiva. (FRAGOSO, 1983: 21).

Ao contrário, a não-fertilização do solo no sistema praticado dá origem, posteriormente, a uma vegetação rasteira e a um solo impróprio para a produção agrícola, funcionando como pasto em uma atividade pecuária de baixa técnica. Neste caso, portanto, se há uma interação entre agricultura e gado, está no caráter sucedâneo do último em relação à primeira, e não na concomitância de sua presença. 
Na produção de café - produto principal da região ao longo do século XIX - verificamos a manifestação dos mesmos padrões com os quais funcionava a cultura de alimentos. O preparo do solo, os instrumentos e o uso da terra eram semelhantes, com a diferença de que na primeira dava-se a extração de sobretrabalho, dado o seu caráter eminentemente mercantil e escravista, não sendo necessariamente o mesmo aplicável na segunda. A divisão das terras entre matas virgens, plantações e capoeiras perpassa o século, e seria ainda uma realidade no seguinte.

Somente na escolha das terras a serem cultivadas com café evidenciava-se alguma preocupação técnica com a atividade, e mesmo assim, como mostra Fragoso, integralmente baseada na prática, sem incursões em conhecimentos de cunho científico de nenhuma espécie. A possibilidade de fazer com que persistissem tais métodos e técnicas advinha unicamente dos interesses da acumulação. Através de um menor gasto de trabalho com uma regular recuperação dos solos utilizados, as matas e sua derrubada permitiam a obtenção de um "sobretrabalho em larga escala", como diz o autor, dada a associação entre os preços internacionais e os custos da produção (FRAGOSO, 1983: 25-29). "O que era poupado em termos de tempo por alqueire se ganhava na possibilidade de se trabalhar extensivamente 'vários' alqueires" (FRAGOSO, 1983: 30).

Assim sendo, entre este segundo modelo e o primeiro, percebemos algumas diferenças fundamentais: a) Paraíba do Sul é uma região de fronteira agrícola aberta, com abundantes reservas de terras virgens até, pelo menos, o final do século XIX e início do século XX, enquanto o sistemas agrário analisado no primeiro modelo fundamenta-se em fronteira agrícola fechada e solos empobrecidos; b) Paraíba do Sul estruturou-se em região de latifúndios e de agroexportação, e em sua decadência, voltou-se para produção pecuária extensiva para o mercado interno (ver adiante), enquanto no mesmo período Niterói já havia direcionado sua economia agrícola para o abastecimento interno; c) a agricultura em Paraíba do Sul, até a sua completa decadência, baseou-se no uso predatório do solo para alimentos e café. A economia agrícola niteroiense já havia passado por esta situação, e neste período responderia ao desafio com o "caráter intensivo" de sua produção de abastecimento.

\subsection{Fronteira agrícola e concentração variadas}

A formação da economia agrária do município de Campos, estudada por Sheila Siqueira de Castro Faria, fornece o terceiro modelo analítico (FARIA, 1986). Observara a autora a existência de áreas em diferentes estágios de ocupação, fator este condicionador da estruturação dos sistemas agrários em cada localidade. Nas freguesias de ocupação mais tardia (Santo Antonio de Guarulhos e Santa Rita da Lagoa de Cima), situadas em terras de maiores altitudes, verificou-se, por intermédio dos Registros Paroquiais de Terras, que a especificação do modo pelo qual havia sido adquirido a terra era muito maior que naquelas freguesias de ocupação antiga (São Salvador, São Gonçalo e São Sebastião), nas quais os detalhes sobre o processo de apossamento já haviam sido diluídos pelas décadas de ocupação. Ainda, nas primeiras, a existência de uma porcentagem pequena, mas territorialmente representativa, de "primitivos posseiros", indicava a dinâmica ainda em curso no momento dos registros, de expansão agrícola na região, diferenciando-as de partes do município em que a paisagem agrícola já se encontrava definida (FARIA, 1986: 114-118).

Nas freguesias de ocupação recente, Sheila Faria indica uma preocupação, por parte dos maiores proprietários, com a legalização de grandes extensões de terras - de um modo análogo a Niterói, na análise de Motta -, como garantia para uma futura expansão das atividades econômicas. Dado que foi o café o principal produto a ser "tentado" nesta fronteira de expansão agrícola, e a extração de madeira outra importante atividade, a expansão extensiva ao longo de um vasto quinhão de terras, e a necessidade da existência de solos e matas virgens se faziam necessários. As declaraçōes de menor vulto - menores que 50 ha - representavam um segundo movimento de apropriação territorial, de pequenos lavradores voltados para a produção de alimentos para o mercado local ou para a subsistência. 
Delineado este dúplice panorama - apossamento e legalização de amplas extensões por parte de cafeicultores / madeireiros, por um lado, e ocupação por parte de pequenos lavradores para uma produção mercantil de subsistência - podemos auferir a situação da fronteira agrícola nesta fração do município de Campos: disputa entre a afirmação do latifúndio ${ }^{3}$ e de uma agricultura de alimentos de pequeno porte. Nas palavras da autora: "Conclui-se, portanto, que havia terras efetivamente livres, não monopolizadas, nessas áreas, até, pelo menos, a década em questão." (FARIA, 1986: 121). A existência de terras livres nestas duas freguesias, correspondente a uma extensão de mais da metade do território do município, transformara-a num polo de atração de trabalhadores em busca de espaço para estabelecimento autônomo de pequenas unidades produtivas. É possível apreender-se esta dualidade na apropriação territorial através da constatação de que, entre os anos de 1840 e 1880, a freguesia de Santo Antônio de Guarulhos, por exemplo, foi a que maior concentração de escravos manifestou em todo o município (dada a atividade cafeicultora em grandes unidades produtivas) e maior aumento de população livre (indicando a ocupação por pequenos posseiros) (FARIA, 1986: 175-180).

As maiores extensões encontradas em Santa Rita e Guarulhos evidenciavam a possibilidade física de anexação de terras contínuas, já que a existência de uma fronteira agrícola aberta, com áreas ainda não totalmente apropriadas, na primeira metade do século XIX, possibilitava a anexação, em contraste com a zona de planície." (FARIA, 1986: 135).

Em N. S. da Penha do Coco, freguesia desmembrada de Guarulhos em 1861, situada no norte do município, área de expansão e fronteira aberta por excelência, ficava configurado de que modo a expansão da cafeicultura caminhou de mãos dadas com o fornecimento de alimentos, principalmente após os anos 1870. Foi esta região a principal responsável pelo abastecimento da cidade de Campos. Através da Estrada de Ferro Carangola, as cerca de 200 pequenas unidades produtivas declaradas, produzindo café, milho, mandioca e feijão, atendiam a um mercado urbano em expansão. A pequena concentração de população escrava (menor do município) e os inventários estudados referentes às pequenas produções, demonstravam o caráter fundamental do trabalho familiar na garantia dos bens de subsistência para o mercado interno (FARIA, 1986: 186-187).

Essa configuração produtiva parece explicar o aumento demográfico progressivo, mesmo após a abolição da escravidão, já que a pequena produção e a existência de terras desocupadas comportavam-se como chamariz para o homem livre ou liberto. (FARIA, 1986: 186).

A agricultura cafeeira escravista ganhou maior espaço no resto da antiga freguesia de Guarulhos pelas facilidades de transporte fluvial. Apesar das semelhanças morfológicas entre esta localidade e Morro do Coco, esta última estava por demais afastada dos mercados para justificar investimentos pesados em escravaria e produção de café. Com a expansão ferroviária, após a década de 1870, os problemas de comunicação foram amenizados, mas este já era um momento em que o trabalho escravo encontrava-se em crise adiantada. A dinâmica cafeicultora escravista não ganha, portanto, a região outrora deslocada das rotas comerciais. Sua expansão - econômica e demográfica - ocorre através da afirmação da produção de alimentos, potencializada pelo estímulo da estrada de ferro. É evidente, entretanto, que os investimentos em ferrovias não se deram tendo como foco a produção de alimentos. Mas podemos afirmar com certeza que a implantação desta facilidade de transportes contribuiu para confirmar na região sua vocação de "subsistência mercantil". A solidez desta atividade foi demonstrada com a crise de mão-deobra decorrente da Abolição, quando Morro do Coco preservou os mesmos níveis demográficos e de atividade econômica, enquanto Guarulhos passou por problemas até posterior recuperação, entre o fim do século XIX a década de 1920.

A propósito, o Censo de 1920 apontara quase três mil estabelecimentos rurais no municípios, sendo 598 deles reconhecidos como "produtores de café". Os demais diziam respeito, certamente, a produtores de gado das mais variadas espécies e cultivadores de milho, feijão e mandioca, entre outros. Uma 
alta média no número de animais de grande porte (gado bovino, equino) e de pequeno porte (aves, suínos, etc.) por unidade indicava orientação mercantil. Além disso, as unidades computadas como produtoras de alimentos somente o foram consideradas pelas dimensões comerciais do empreendimento, o que deixava de fora do cômputo as lavouras de subsistência no interior de unidades criadoras de animais ou de culturas de café e cana (FARIA, 1986: 207-209).

Ausência de escravos para implantação de lavouras de grande porte, terras livres que 'chamavam' população livre ou liberta do cativeiro e meios de escoar a produção, determinaram a produção de alimentos, inclusive açúcar e café, direcionada ao mercado municipal (FARIA, 1986: 195).

Nas freguesias de planície, de ocupação antiga e produção canavieira, pouco informou-se a respeito da origem das terras declaradas nos Registros Paroquiais. Pode-se encontrar uma relativa estabilidade na questão fundiária, o que não deve ser confundido com a inexistência de conflitos.

Todo o passado de luta pela terra, na planície, e a vitória dos que lá estavam, na década de 1850, mesmo com terras próprias, mas alugadas a outros, tornava inquestionável o direito a elas por parte dos não arrendatários (FARIA, 1986: 186).

No que se refere à dimensão das unidades produtivas, a planície campista caracterizou-se pelas unidades de menor porte, principalmente se comparada ao nordeste brasileiro. Isso não significa, portanto, tratar-se de uma região de pequenos proprietários: a ocupação antiga através do sistema sesmarial vigente na Colônia, e os momentos posteriores ao fim deste regime entre 1822 e 1850 haviam consolidado o latifúndio. Após o estabelecimento deste monopólio, frações substanciais destas grandes fazendas foram submetidas ao arrendamento.

Havia, então, a grande propriedade (pelo menos consensual, já que, no período de 1822 a 1850, nenhuma lei regulamentava a legalização de terras), o que não havia era a generalização da grande produção (FARIA, 1986: 124).

As razões para tal característica da paisagem rural da planície esbarram em elementos geográficos: a existência de pântanos e lagoas dificultariam a unidade territorial.

No entanto, considerando-os insuficientes, Sheila Faria sugere que, em função das condições de transporte e comunicações internas da Baixada Campista com os portos de Macaé e do Rio de Janeiro, problemáticas até a metade do século XIX, o impulso à expansão da produção deveria ser muito pequeno.

Daí decorre a aceitação, pelo grande proprietário legal da terra, (o sesmeiro), também ele produtor de açúcar (...) que existissem, em suas terras ou em suas vizinhanças, inúmeros pequenos senhores de engenho (FARIA, 1986: 130).

Ou seja, até a implantação dos engenhos a vapor (por volta dos anos 20 do século XIX) e dos engenhos centrais (final do século) deu-se a existência não só de pequenas lavouras de cana, como também pequenos empreendimentos industriais para o processamento desta mesma matéria-prima, geralmente reunidos sob o poder de um mesmo ator social.

Outro importante fator reside na própria natureza da cultura da cana-de-açúcar. Diferentemente da produção de café, com alto poder de exaustão do solo, a cana traz pouco desgaste à terra, permitindo, portanto, sua criação em áreas de menor porte, sem a necessidade intrínseca, dentro de um sistema de exploração predatório, da existência de novas terras virgens.

As freguesias de ocupação mais recente, nas terras altas, tiveram uma concentração fundiária muito mais intensa, o que se explica pelo "projeto cafeicultor" na região, malogrado por fatores geográficos e pela crise decorrente do fim do tráfico negreiro. Na segunda metade do século XIX, tendo sido a cultura da cana a predominante no município, as regiōes onde se tentou a implantação da cafeicultura acabaram por transitar entre diversas culturas, principalmente a de alimentos e também de açúcar para 
o mercado urbano de Campos, tornando-se, segundo Sheila Faria, o "celeiro" do município. Vale lembrar que mesmo o açúcar produzido nas regióes de planície tinha como mercado o Rio de Janeiro, não se configurando, portanto, como produção de exportação. Dadas as dificuldades de transporte e a baixa qualidade do produto, comparado ao similar nordestino, não se justificava a exportação, configurando a área, assim, como abastecedora do mercado interno (FARIA, 1986: 139-140).

Vemos, portanto, como o terceiro modelo analisado situa-se a meio caminho entre uma região de fronteira fechada e concentração fundiária - teoricamente expressa através do primeiro modelo - e de fronteira aberta e desconcentração fundiária - caso do quarto modelo, a ser exposto adiante. A divisão do município entre áreas de ocupação antiga na Baixada Campista, com culturas mercantis de cana-de-açúcar, e de ocupação recente nas terras altas, com pequenos lavradores de alimentos disputando espaço com fazendeiros cafeicultores, assemelha-se, de certo modo, com o exemplo do município de Magé (SAMPAIO, 1994: 1-2) no que tange exclusivamente a existência numa mesma região de áreas de fronteira fechada e aberta (dada a dedicação quase que "monocultora" do município à cultura de alimentos). O que importa para os objetivos deste estudo é a possibilidade do estabelecimento, com relativa independência, de pequenos lavradores em áreas de expansão e os impactos desta situação sobre a formação do mercado de trabalho.

\subsection{Fronteira agrícola aberta e desconcentração fundiária}

O quarto e último modelo que pretendemos delinear fundamenta-se na análise empreendida por Hebe M. Gomes de Castro para os sistemas agrários no município fluminense de Capivary, na crise do modo de produção escravista e transição para o trabalho livre (CASTRO, 1985). Trata-se de um esforço intelectual fundamental para a afirmação dos lavradores livres pobres como objeto de estudo da história agrária brasileira ao longo de toda a sua trajetória, bem como para a relativização da plantation como forma por excelência de atividade econômica no agro nacional. Tratou-se o município de uma área de fronteira agrícola aberta, sendo palco, no século XIX, de implantação de uma sociedade escravista e de um processo embrionário de expansão cafeeira, voltada entretanto para o consumo interno. Condições naturais desfavoráveis marcaram a região, no entanto, com o estigma da pobreza, dado que o café ali produzido fora incapaz de competir com produções mais eficientes e de melhor qualidade. As culturas de alimentos, realizadas em conjunto com os cafezais, acabaram por se sobressair. Mercados insuficientes e a baixa densidade populacional tornavam Capivary uma área de poucos atrativos ao grande empreendimento de exportação, e um farol para pequenos lavradores com objetivo de estabelecerem culturas de subsistência com alguma inserção mercantil.

O desfecho da crise do modo de produção escravista no quarto modelo é, portanto, diametralmente oposto ao equivalente no primeiro e segundo modelos: fronteira fechada $v$ s. fronteira aberta, pequenas propriedades e trabalho independente $v s$. grandes propriedades e extração de sobretrabalho, respectivamente. Capivary foi uma região inteiramente de ocupação tardia. Enquanto, no século XVIII, as culturas de cana e produção de açúcar espalhavam-se pelo interior da Baixada Fluminense, a região era ainda coberta por florestas tropicais, sendo identificada somente ao final deste século, alguma ocupação humana baseada em quatro fazendas, provavelmente de produção canavieira. Somente na primeira metade do século XIX é que a ocupação efetiva iniciou-se em Capivary: as parcas possibilidades da cultura cafeeira diante da riqueza oferecida pelas zonas serranas criava desde o início uma desvantagem comparativa. A exploração de madeira, por sua vez, mostrou-se negócio de grande lucratividade (CASTRO, 1985: 54-56).

A propriedade fundiária configurou-se no século XIX em função do surto cafeeiro fluminense, do qual o município também foi partícipe, ainda que seus impactos tenham sido limitados, como já indicamos. Em sua expansão pela província, no início dos oitocentos, a ocupação das terras dava-se de maneira análoga ao Vale do Paraíba, por meio da expulsão de populações indígenas, derrubada de matas e emprego de escravos. Somente ao amenizar-se o impulso expansionista, a concorrência entre regiōes com melhores condições naturais (as terras serranas, de maiores altitudes) definiria o destino da cafeicultura, não só no município, como na Baixada Fluminense como um todo. 
A produção de Capivary sobrevivente ao surto de curto fôlego do café nas encostas (...) localizando-se nas vertentes dos contrafortes da Serra, amplia-se, no entanto, em crescentes desvantagens, na retaguarda dos futuros barōes do Vale (CASTRO, 1985: 80).

Ainda que sua força de expansão tenha sido contida pelas circunstâncias em que se deu, a análise do conjunto dos Registros Paroquiais empreendida por Castro indicou uma situação de concentração fundiária bastante evidente, o que era de se esperar neste momento, tendo em vista o caráter de fronteira agrícola aberta, a ocupação recente da região e a atividade cafeeira. Em suma, de 201 registros com informações suficientes demonstraram, segundo a autora, que 19 terrenos (de mais de $400 \mathrm{ha}$ ) correspondiam a mais da metade da área recenseada, enquanto 65 outros (de menos de 41 ha) representavam 3\% do total (CASTRO, 1985: 66).

Paralelamente a esta realidade, detectada por intermédio do registro legal de propriedade fundiária, defende Castro que os anos 50 também foram marcados pela expansão de uma "outra fronteira", composta por pequenos lavradores, fator de contraponto à concentração fundiária identificada "oficialmente". Analisando a demografia da região nesta década, percebeu que a concentração de população escrava, comparada ao percentual de homens livres, era muito inferior ao restante da província do Rio de Janeiro, indicando que significativa parcela das terras - que não era ocupada pela cultura de café -, vinha sendo destinada à produçôes de subsistência. "Numa regiāo recém-desbravada, a fronteira agrícola encontra-se igualmente aberta para simples sitiantes ou ricos fazendeiros." (CASTRO, 1985: 80). A formalização de uma infraestrutura (principalmente em termos de comunicação) adequada para as culturas comerciais de alto valor acabava por condicionar igualmente o ritmo de ocupação de áreas de fronteira com roças de mantimentos. $\mathrm{O}$ avanço das fazendas ou incorporava esta população como agregados privando, portanto, o produtor de sua independência -, ou os expulsava para mais adiante. Os efeitos, portanto, da crise de mão-de-obra decorrente do fim do tráfico, somados à desvantagem de sua cafeicultura diante das áreas de maior eficiência, afetaram Capivary a ponto de levarem a uma diminuição da população escrava e aumento absoluto da população livre, com consequente estancamento da ocupação de áreas de fronteira e reservas florestais pela agricultura de café, liberando estas áreas para a incorporação de lavradores pobres subjugados a proprietários (CASTRO, 1985: 81-84).

Vemos, portanto, que no movimento de expansão econômica no município, formavam-se duas categorias de produtores diretos: aqueles que tinham vínculos estabelecidos com proprietários de terras - através, também, de práticas de coerção - e aqueles que, lançando mão das possibilidades da fronteira aberta, estabeleceram-se nela com relativo grau de independência. Entre estes, a produção era organizada com objetivos de subsistência, com ocasional inserção dos pequenos excedentes nos mercados locais a fim de obtenção de outros produtos que os lavradores não pudessem obter pelo próprio trabalho. Verifica-se uma incapacidade ou a falta de interesse na reprodução ampliada dos empreendimentos, para a obtenção de lucros maiores. "Esses lavradores pobres encontravam-se alheios, portanto, a qualquer dinâmica regida pela lógica de reprodução do capital comercial socialmente preponderante. ”(CASTRO, 1985: 160-161).

\section{Sistemas agrários e transição para o trabalho livre}

\subsection{Proletarização do pequeno agricultor}

Tratemos agora de compreender os rumos tomados pelos diferentes sistemas agrários em função do processo de abolição do trabalho escravo. No caso de Niterói - região de fronteira agrícola fechada, segundo Motta - temos também de compreender quais foram os impactos da Lei de Terras sobre uma importante parcela da população conformadora da paisagem socioeconômica da região, as famílias de sem-terras. Um elemento importante a ser ressaltado, e que funciona como ponto de partida das transformaçóes pós-1850, é a existência de acesso à terra por parte de lavradores expropriados deste meio de produção. Ao contrário do que poder-se-ia inferir acerca das condições sociais de uma região suposta- 
mente com carência de terras livres, a dificuldade de obtenção de terras para o trabalho agrícola foi mediana, dado que desde a primeira década do século XIX a prática do arrendamento vigeu na localidade. Da mesma forma, a autonomia desfrutada pelo arrendatário até pelo menos os anos 1850 foi uma marca distintiva do sistema agrário erigido em Niterói (MOTTA, 1989: 65).

A acumulação a partir do arrendamento de terras parece ter sido, como nos indica Motta, um expediente comum em meio aos proprietários de terras. Ao menos tal situação permitira a instalação de pequenos lavradores expropriados da terra como produtores autônomos, tendo a oportunidade de edificarem moradia, culturas e outras benfeitorias. Poderiam utilizar-se na terra alugada do trabalho de um número limitado de escravos (situação que os fazia privados da terra somente, mas não da riqueza fundamental naquela sociedade, a propriedade integral do trabalho alheio) com os quais plantavam alimentos como mandioca, frutas e café, em sua maior parte destinado ao mercado da Corte. O pagamento de renda monetária pelo usufruto da parcela, expediente comum desde a primeira metade dos oitocentos, demonstrava que praticava-se na região, por meio da pequena unidade produtiva, uma agricultura comercial com lucratividade suficiente para sustentar o pagamento de renda da terra (MOTTA, 1989: 68).

A autonomia no que tange a posse, portanto, parecia assegurada na medida em que a extração de renda não comprometia os negócios. Mesmo sem terras, é possível falar na existência de um pequeno produtor "independente" na região, por vezes até escravista. A possibilidade de acumular algum capital não levou os lavradores sem terras, neste primeiro momento, a se lançarem à aquisição de parcelas, pelo fato do cativo constituir-se em renda capitalizada mais lucrativa e pela segurança que a prática do arrendamento oferecia (MOTTA, 1989: 77).

A isso se somava o fato de que na região em questão alugar terras consistia em uma atividade rentável, ainda que não em termos de magnitude, mas em termos de segurança na aplicação. Motta não afirma textualmente, mas podemos sugerir que tal se dê pela proximidade com o mercado consumidor do Rio de Janeiro e pela ausência de terras livres (MOTTA, 1989: 78).

Apesar disto, a autonomia do pequeno lavrador sem terras não era plena, e isso fica claro por meio da análise de sua relação com o mercado a que atendia. Afirma Motta que as oportunidades proporcionadas pelas dimensôes do mercado consumidor da Corte levaram à prática do monopólio dos portos locais por parte da classe dominante agrária e do capital mercantil. Os custos para a instalação destas benfeitorias transcenderiam a capacidade regular de financiamento do pequeno produtor, contribuindo tal fato para a concentração da propriedade dos mesmos. Assim sendo, seria comum verificar-se a relação entre grandes proprietários de terras e donos de portos, sendo frequentemente as mesmas pessoas. Demonstra a autora, portanto, que a proximidade com o centro de consumo, que deveria reduzir os custos de transporte, não consistia em um mecanismo de estímulo de preços para o produtor direto, já que as facilidades em termos de locomoção e distribuição das mercadorias em direção ao Rio de Janeiro beneficiavam diretamente os detentores dos monopólios sobre os portos. "Os pequenos produtores, por não poderem comercializar livremente a produção, estavam submetidos àqueles que detinham controle dos portos locais." (MOTTA, 1989: 53).

Portanto, o empreendimento de promover a circulação da produção exigia montantes de capital além das possibilidades desta parcela social. Sendo assim, a dominação sobre o produtor comercial "autônomo" ocorria principalmente nesta esfera.

Sempre que a produção de pequenos lavradores se orienta para o mercado (pequena produção mercantil) a relação entre tais produtores e comerciantes é bastante desvantajosa para os primeiros (MOTTA, 1989: 79).

Era portanto através da comercialização e financiamento da produção que diferentes parcelas da classe dominante - por meio do controle dos portos locais - interferia na sobrevivência do lavradores arrendatários. Nesta mesma linha atuavam os "vendeiros", pequeno capital comercial e parte da parentela de grandes famílias, que operavam nas terras de um proprietário com sua permissão, fornecendo gêneros diversos aos sem-terra e deles tornando-se credores. 
Parece-nos, portanto, que apesar da precariedade dos dados, podemos afirmar que boa parte das dívidas passivas dos 'sem-terra' originava-se de suas relações com os proprietários de terras e/ou donos de portos. $\mathrm{O}$ restante da dívida se disseminava em produtos adquiridos por esses lavradores em razão de não poderem ser produzidos por eles (MOTTA, 1989: 81).

As transformaçóes advindas dos anos 1850 agravaram ainda mais os fatores de dependência do produtor para com o capital comercial, conduzindo a uma situação caracterizada por Motta como de "proletarização" do pequeno proprietário, fosse ele sem terra ou detentor de pequenas parcelas. O processo de absolutização da propriedade da terra e sua mercantilização levou a um incremento na renda da terra a ser extraída do lavrador, colocando-o em uma situação paradoxal de ter de corresponder à essa tributação "inflacionada" por meio da otimização da produção num contexto de recomposição do fator trabalho, consubstanciada no fim do tráfico negreiro e no encarecimento do valor dos cativos africanos, e portanto, na menor acessibilidade à força de trabalho (MOTTA, 1989: 152-153). Mesmo que se pudesse sugerir que o aumento da renda da terra indicasse um momento de prosperidade dos arrendatários - a ponto dos proprietários exigirem maiores quantias pelo acesso à sua terra, como diria Adam Smith -, o momento pouco propício para tal, acrescido de outros indícios, nos dizem exatamente o inverso.

Afirma a autora que nos primeiros anos após o fim do tráfico o aumento dos preços dos alimentícios pode ter vindo a ser favorável também aos lavradores sem terra, ao menos por um espaço de tempo determinado. No entanto, a crise dos anos 1850 viria logo a impor um pesado fardo por meio da queda de produtividade dos escravos ainda possuídos, da dificuldade de renovação da mão-de-obra e, por sua vez, do decréscimo no valor dos bens produzidos. A utilização de cativos velhos e doentes até os últimos dias de vigência legal do trabalho escravo demonstraria a negação do pequeno lavrador sem terras em proletarizar-se, inserindo-se no mercado de trabalho através da venda de sua força de trabalho (MOTTA, 1989: 167).

A segunda metade do século XIX foi, assim, marcada pelo crescente endividamento para com os detentores do financiamento e dos meios de transporte.

Os dados parecem demonstrar que estava em curso um processo de empobrecimento desses lavradores: enquanto subia a renda a ser paga decaía o valor das culturas (MOTTA, 1989: 157).

Havia, portanto, uma aparente contradição, ou seja, a crescente demanda de seus produtos correspondia ao seu crescente endividamento (MOTTA, 1989: 161).

Tal fato demonstra que, apesar de ser indicado por Motta, seria bem pouco provável que o aumento dos preços dos alimentícios tivesse vindo, em qualquer momento, a beneficiar o produtor direto. A crise do escravismo e a dominação do capital comercial e dos senhores de terras teriam conduzido, assim, a uma situação de perda de autonomia por parte do lavrador de pequeno porte. O processo de "caipirização", ou seja, de formação de pequenas ocupações de subsistência, com inserção mercantil variada, não verificar-se-ia no município de Niterói, em função do fechamento da fronteira agrícola, tornando o arrendamento a única forma de acesso à terra (MOTTA, 1989: 157-158).

\subsection{Coerção extraeconômica: parceiros, meeiros e colonos}

Diferentemente da prática comum numa região de fronteira fechada como Niterói, de arrendamento de parcelas no interior das fazendas e do sustento dos proprietários por meio deste negócio, Paraíba do Sul, nosso segundo modelo, foi uma região típica de grandes unidades produtivas e grandes propriedades, onde se empregou trabalho escravo em larga escala e voltou-se a produção para o mercado de exportação. Num contexto desta natureza, podemos perceber claramente de que modo se efetuava a relação entre mercado interno e economia escravista. O objetivo é, evidentemente, indicarmos como este padrão de relacionamento persistiu nesta e em outras regiōes após 1888 . No caso de Niterói em particular, vimos como a perda de autonomia do lavrador sem-terra diminui suas possibilidades de acumulação, na maior parte das vezes fazendo com que fosse incorporado às fazendas como mão-de-obra, 
"proletarizando-se", como defendeu Motta. Ainda assim, com graus diferenciados, podemos dizer que o produtor direto manteve um elevado grau de autonomia em relação ao mercado na sua reprodução. Tal o foi para Niterói, e especialmente em Paraíba do Sul: através da descrição de fazendas, de seus equipamentos e das profissões dos escravos é possível sugerir que a plantation escravista também funcionava com uma pequena dependência de trocas externas (FRAGOSO, 1983: 65).

A investigação dos inventários levantados por Fragoso indicou a presença de maquinaria destinada ao beneficiamento de gêneros ligados à subsistência nas fazendas de café, sendo a mandioca e o milho os mais referenciados. $\mathrm{O}$ mesmo valia para unidades produtivas de menores dimensões. Através da discriminação das colheitas, verificamos igualmente a plantação de alimentos diversos. A capacidade produtiva das fazendas estudadas era significativa no cultivo de cereais.

E se a isso acrescentarmos que aqueles gêneros eram beneficiados no próprio interior da fazenda, em seus moinhos ou casas de farinha, podemos deduzir que os custos com a reprodução anual da fazenda eram muito reduzidos (FRAGOSO, 1983: 56).

Outra boa medida de integração das grandes unidades produtivas de Paraíba do Sul no circuito do mercado interno foi buscada pelo autor a partir da análise das contas das fazendas. Os maiores gastos nas unidades pesquisadas diziam respeito às despesas com força de trabalho escrava, consistindo em dispêndio com serviços, aquisição de gêneros produzidos pelos cativos e, num outro polo, a compra de bens no mercado regular. Atestando o fato de que a maior parte dos itens necessários para o funcionamento da unidade produtiva era fornecida pelos próprios escravos, Fragoso conclui que a reprodução da mão-de-obra ocorria com relativa independência em relação aos circuitos mercantis internos:

(...) o fato do escravo vender ele próprio gêneros à fazenda, nos leva a crer que este reproduzia parcialmente a sua vida material à margem do mercado. Isto é, estes mantimentos vendidos por ele seriam excedentes de sua própria produção (FRAGOSO, 1983: 67). ${ }^{4}$

Ou seja, sugere o autor que os cativos efetuariam uma produção de subsistência com ligeira inserção mercantil. Isso significa que a autonomia relativa da plantation seria uma suposição legítima, ainda que admitir este fato pressuponha que ponhamos abaixo a ênfase no aspecto "monocultor" da mesma. A produção interna de subsistência da unidade produtiva significava, neste contexto, uma grande vantagem em termos de rentabilidade da empresa, já que

(...) este tipo de despesa seria bem maior caso fosse computado como compra de mercadorias o que os escravos produzem mas não vendem, mas sim consomem. Isto é, caso não existisse aquela produção de alimentos feita pelos escravos e, portanto, a fazenda fosse obrigada a comprar o seu equivalente no mercado (FRAGOSO, 1983: 69).

O fenômeno de distanciamento em relação aos pressupostos básicos do modo de produção capitalista evidenciava-se também no modo como efetuava-se o pagamento de trabalhadores contratados para tarefas especializadas ou temporárias (como feitores, carpinteiros, etc.). No caso dos trabalhadores permanentes, o pagamento de salários dava-se num espaço de tempo bastante esgarçado. Neste ínterim em que indispóem dos recursos monetários relativos à venda de sua força de trabalho, suas necessidades eram atendidas por meio do fornecimento direto de bens, por meio daquilo que chamou o autor de "pagamento não-monetário".

Nesta medida, nota-se que o tipo de relação estabelecida entre o fazendeiro e os empregados não consiste propriamente em relação assalariada em strito-sensu e, por outro lado, observa-se a fragilidade do mercado e da circulação monetária presente na região neste período (anos de 1880) (FRAGOSO, 1983: 70).

Como dissemos anteriormente, Paraíba do Sul consistia de uma região de grandes fazendas escravistas voltadas para o mercado externo. Da mesma forma, enunciamos que, diferentemente da produção de ali- 
mentos na mesma localidade, o café era produzido por intermédio da extração de sobretrabalho por parte da classe proprietária. Tratando-se de uma região de fronteira agrícola aberta (o que se depreende através dos mecanismos de reprodução do sistema agrário), vejamos como Fragoso analisou a relação entre grande unidade produtiva, apropriação do trabalho alheio e formação de uma economia de camponeses autônomos.

Em uma situação como a apontada, seria imprescindível, segundo o autor, a criação de mecanismos econômicos e "extraeconômicos" que viessem a compelir o trabalhador ao labor em prol de outrém. A baixa relação população-terra criava uma situação de inadequação do emprego de mão-de-obra assalariada, levando a classe dominante agrária a lançar mão ou do escravismo (enquanto este foi presente e viável) ou de artifícios que viessem a privar o homem da terra, como a absolutização da propriedade, por exemplo. A possibilidade de reproduzir sua existência por meio da obtenção de alimentos com pequeno dispêndio de trabalho (extensivamente, portanto) ainda contribuiria para, em condições em que não apresentassem-se os proprietários de terras, o produtor furtasse-se ainda mais à prestação de trabalho a terceiros.

Além da configuração da necessidade de um "sistema repressivo de mão-de-obra" para extração de sobretrabalho - de forma semelhante àquela conceituada por Moore Jr. -, a dita associação do trabalhador aos meios de produção, ou seja, a elaboração por parte dele próprio, na agricultura, dos bens necessários à sua reprodução como força de trabalho, jogava papel importante dentro do cenário delineado. Como os alimentos eram produzidos num sistema de uso do solo que exigia pouco trabalho, garantia-se o fornecimento de "bens-salário" (usando a expressão de um modo mais livre, evidentemente) com baixos custos para o proprietário, já que teria preservada a continuidade da mão-de-obra que explorava sem ter de desviá-la por muito tempo da produção de bens de exportação, ampliando, portanto, a margem de sobretrabalho extorquido. Da mesma forma, pela subsistência não passar pelo mercado, não fazia com que tivessem de ser pagos salários minimamente compatíveis com a preservação do homem como força de trabalho e, principalmente, suscetíveis às flutuações de preços dos gêneros de primeira necessidade, podendo vir a comprimir ainda mais os índices de apropriação de trabalho excedente (FRAGOSO, 1983: 95-97).

Em outras palavras, por um lado, frente à possibilidade de desenvolvimento de uma agricultura extensiva de alimentos como base da vida autônoma do produtor direto (dada pela baixa relação trabalho-terra), a classe dominante agrária cria mecanismos de controle sobre a força de trabalho. Por outro lado, esta mesma forma de agricultura de alimentos é levada para dentro da fazenda, transformando-se aí em um elemento de extorsão de sobretrabalho (FRAGOSO, 1983: 97).

Tal forma de reprodução da força de trabalho permite a ampliação da exploração sem a necessidade do recurso a implementos tecnológicos nem de alteração das técnicas, dando vida à persistência da tradição e da repetição neste sistema agrário (FRAGOSO, 1983: 100).

É compreensível que uma forma de exploração agrícola com tão alto grau de degradação do solo, sem a recuperação por meio do dispêndio de trabalho e capital, tenha vindo, num determinado ponto, a esgotar-se. Assim sendo, o segundo modelo que aqui analisamos deu sinais de profunda ruptura nos anos 80 do século XIX. A expansão por meio da incorporação de terras virgens esbarrou na eliminação das mesmas. Os pastos, consequência do enfraquecimento das capacidades férteis da terra, tomaram conta do cenário agrícola nos primeiros anos do século XX, ao passo que as matas, fração mais representativa do valor estimado de uma fazenda, praticamente desapareceram. Os cafezais, em processo de envelhecimento entre os anos de 1850 e 1910, não foram renovados, demonstrando uma gradual perda de poder de acumulação por parte dos empreendimentos comerciais agrícolas. A ruptura ambiental ficava atestada com ampliação dos ataques de pragas e formigas; se não se investia recursos na recuperação da fertilidade das terras, fazia-se no uso de produtos químicos no combate aos males que tomavam a já cambaleante produção agrícola (FRAGOSO, 1983: 109-113).

O desaparecimento das matas na região seria conjugado à crise no abastecimento de mão-de-obra e à ruptura do escravismo, conduzindo, ao longo da segunda metade do século XIX, à consciência da necessidade de equilibrar os pratos da balança por meio da poupança de trabalho através de implementos 
técnicos no processamento de matéria-prima agrícola, transferindo trabalhadores destas atividades para a lavoura. Foi na mesma medida importante o desenvolvimento e barateamento dos transportes, decorrentes da expansão ferroviária.

Mesmo após a abolição da escravidão, se percebe um certo desenvolvimento das técnicas de beneficiamento, através da presença de debulhadores americanos, máquinas de beneficiamento movidas a vapor, beneficiadores Lidgerwood, etc., nos inventários das fazendas de café (FRAGOSO, 1983: 116).

Isso não significou, por sua vez, alguma alteração revolucionária no sistema agrário, dado que as técnicas de produção pouco alteraram-se.

Ao possibilitar a economia de mão-de-obra, a melhoria do beneficiamento permite a manutenção, não a mudança, das técnicas da lavoura, garantindo assim a reprodução do sistema agrário (FRAGOSO, 1983: 116).

Ainda, cabe lembrar que, dados os altos custos envolvendo a compra de maquinarias, somente os proprietários com condiçôes de reproduzirem suas unidades - ou seja, aqueles que ainda tivessem matas virgens nas suas terras - tinham capacidade de modernizar-se e poupar mão-de-obra (FRAGOSO, 1983: 112-117).

Assim sendo, definhara-se o sistema agrícola em Paraíba do Sul pelas condições técnicas em que foi construído, não sendo uma consequência direta do fim do tráfico de escravos nem da "crise" do café. A expansão da produção cafeeira buscará em novas terras virgens - portanto, numa nova região de solos férteis e de fronteira agrícola aberta - suas possibilidades de perpetuação. São Paulo foi palco deste movimento, com incorporação de mão-de-obra qualitativamente distinta, mas dentro de marcos que a definem especialmente como uma região de fronteira aberta onde se almeja a extorsão de sobretrabalho. Os fluxos imigratórios de estrangeiros para São Paulo não seriam equiparados em nenhum momento às cifras de imigrantes recebidos em regiōes esgotadas para o cultivo de café, como é o caso de partes importantes do estado do Rio de Janeiro após 1890 (FRAGOSO, 1983: 119-124).

Apesar da crise de seu produto principal, a agricultura da região sobreviveu, adaptando-se à novas formas de trabalho, mas dentro da mesma lógica de produção extensiva. $\mathrm{O}$ arrendamento toma parte como importante relação de acesso à terra, mas não nos marcos do arrendamento capitalista. O proprietário conferia aos contratantes o direito de cultivo de alimentos, e no caso do café, tinham a obrigação de deixar a metade do montante produzido ao proprietário, além de estarem incumbidos da colheita e de outras obrigações como conservação das benfeitorias, insetização, replantio, etc. A ação do arrendatário sobre a terra é limitada, verificável pela sua falta de acesso às matas virgens restantes. Evidentemente o termo "arrendamento" deve ser usado neste caso em sentido genérico, dado que descreve relações de meação, colonato e parceria sob uma mesma rubrica (FRAGOSO, 1983: 125).

Fragoso aponta a persistência do sistema de sustentação da mão-de-obra baseado na produção interna de subsistência nas fazendas. Conclui desta forma baseado na análise de inventários produzidos entre os anos de 1890 e 1920, constatando neles significativa presença de máquinas destinadas ao preparo e beneficiamento de alimentos, corroborando ainda com esta afirmação os dados fornecidos pelo Censo de 1920. É possível perceber como a cultura do café permanecia associada à de alimentos, mesmo num momento de decadência do primeiro produto (dada a crescente incapacidade de reprodução das fazendas pelo esgotamento dos solos). Pode-se sugerir, inclusive, que a cultura de alimentos foi ganhando uma importância cada vez maior na medida em que a regiāo passava a direcionar suas atividades para o mercado interno (FRAGOSO, 1983: 133).

É nas circunstâncias de persistência / definhamento do sistema agrário da economia de exportação que se dá a construção das relações de produção na agricultura da região pós-escravidão. Em outras palavras, o entendimento da forma como assume essas relaçōes de produção deve ser procurado na manutenção das técnicas agrícolas, isto é, no sistema de uso da terra que continua a dominar a paisagem agrária da região. E 
ainda, na diminuição da capacidade de reprodução do sistema agrário representada pela gradativa extinção das matas (...) e na carência de mão-de-obra (FRAGOSO, 1983: 134-135).

Dentre as mudanças apresentadas com o fim do modo de produção escravista, evidencia o autor como marca da região, a sujeição do trabalhador ao proprietário. Dado que, segundo Fragoso, a Lei de Terras teria logrado em fechar as áreas de expansão agrícola ao acesso por parte dos pequenos lavradores, em função da mercantilização, a terra continuaria a ser um privilégio que somente poderia ser concedido a partir da vontade do senhor rural, em troca das obrigaçôes ou pagamentos que fossem-lhe mais convenientes. "Este mecanismo de tornar cativa a terra, transformava a terra em um cativeiro para o trabalhador." (FRAGOSO, 1983: 135). Dada a baixa relação entre população e terras, e a possibilidade de formação de uma agricultura de subsistência autônoma, a classe dominante agrária asseguraria justamente a dominação sobre o trabalhador liberto por intermédio da transformação da propriedade fundiária em capital. E os efeitos de tais implementos teriam sido tão veementes que, baseado em relatórios oficiais, afirmou o autor, assim como o fez Motta para o município de Niterói: "Em 1898, não existiam terras devolutas em Paraíba do Sul." (FRAGOSO, 1983: 137).

O sistema de colonato-parceria, lançando mão do contingente de escravos emancipados e de suas famílias, basicamente fazia com que se trocasse a permissão de lavrar culturas de subsistência (com eventual venda de excedente, ponto este fundamental para os objetivos do presente estudo) e alguma soma em dinheiro ou em parte da cultura de grande valor comercial (como o café) pela entrega de sobretrabalho ao proprietário da terra.

Desse modo, nessa relação de produção o trabalhador produzia e se apropriava de parte de seus meios de subsistência, sem a mediação do mercado, não consistindo assim propriamente em relações capitalistas de produção. Ao contrário destas últimas, o colono aparecia 'associado' aos meios de produção (do fazendeiro), ele não vendia contínua e sistematicamente a sua força de trabalho recebendo em troca um salário com o qual fosse retirar todos os seus meios de subsistência, enquanto mercadorias, da circulação (FRAGOSO, 1983: 138-139).

Por fim, o regime de exploração da terra teria feito com que, no período entre 1870 e 1920, as possibilidades de reprodução das formas de agricultura em Paraíba do Sul tenham tornado-se exíguas ao ponto da inviabilidade. Alimentos ou café, as culturas cederam espaço ao avanço da pecuária, estruturada, dentro das condições sociais e da distribuição de propriedade, em métodos extensivos. A formação de pastos nas terras desgastadas pelo uso continuado e predatório fazia com que a pecuária, antes atividade acessória às plantações de exportação, se tornasse a atividade principal. Tratou-se de um processo gradual, que não chegou a configurar a localidade como uma área econômica de criação de gado. Formou-se como resposta ao definhamento das possibilidades de continuação do sistema agrário do século XIX. As necessidades de mão-de-obra decorrentes da atividade pecuária eram compatíveis com a oferta de braços, tornando-se portanto uma alternativa (FRAGOSO, 1983: 144-155).

Nesta medida a pecuária em Paraíba do Sul, se desenvolve sobre aquilo que 'sobrou' do sistema agrário da economia de exportação. E isso não só nos informa que não houve uma modificação nos métodos agrícolas de tal forma que permitisse a recuperação dos solos para a agricultura, mas como também nos indica o tipo de pecuária desenvolvida (FRAGOSO, 1983: 152).

A perda de liberdade do produtor direto foi também a forma pela qual expressou-se a transição da escravidão para o trabalho livre em Campos. Dados os parcos fluxos imigratórios para a região, conduzido em maior parte para as áreas de fronteira aberta de São Paulo, a coação ao trabalhador foi um problema a ser enfrentado, a fim de resolver-se a questão do ingresso numa nova dinâmica produtiva. Nas áreas açucareiras da planície, foram reduzidos à relações de colonato e parceria os homens libertos do cativeiro e os antigos pequenos arrendatários. Estes últimos foram empobrecidos pela situação econômica pós-1850, que direcionou sua atividade ainda mais para o trabalho familiar, auxiliado pelos poucos cativos que ainda restaram sob seu poder. 
Assim como em Niterói, duvida-se da possibilidade destes produtores, outrora com relativo grau de independência, terem conseguido acumular riqueza. A "industrialização" no campo com a fundação de engenhos centrais retirava-lhes o papel no processamento do produto. Os pagamentos pelo aluguel da terra, outrora feitos em moeda, foram substituídos praticamente pela meação, dando-se por meio da entrega de parte da produção. Em suma, perdia o produtor o direito de cultivar o que mais vantagens the trouxesse.

Estabelecia-se, assim, o amplo domínio do proprietário sobre o lavrador e o resultado do seu trabalho, com a exclusividade que aquele passou a dar ao plantio de cana-de-açúcar necessária ao seu engenho (FARIA, 1986: 280).

A existência de um amplo contingente de homens livres na região canavieira, resultado de fluxos migratórios, ainda no período escravista, garantia mão-de-obra para as atividades agrícolas diante da falta do trabalho escravo, e principalmente depois de sua extinção. A existência de trabalhadores livres sem terras fornecia contingente empregável, estabelecidos como força de trabalho eventual ou como "situados". Esta última categoria diz respeito a lavradores ocupantes de terras de algum proprietário, que obtém o direito de trabalharem pela sua subsistência em troca de prestação de serviços diversos, funcionando como mão-de-obra de baixo custo, de fácil arregimentação e fixada à terra.

A consciência da necessidade de coação sobre o trabalhador com o fim do escravismo ficou demonstrada na opinião de Arrigo de Zettiny, em artigos publicados no ano de 1894 no Jornal do Commercio, onde sugeria aos lavradores o emprego de "coações que deram certo" para preservarem os níveis de atividade anteriores a 1888, reafirmando a importância do sistema de colonato-parceria na substituição ao cativeiro (FARIA, 1986: 282-285).

Ao contrário das condições socioeconômicas encontradas no Nordeste - abundância de mão-deobra sazonal, territórios áridos expulsando trabalhadores, fronteiras agrícolas estabelecidas -, no município de Campos não encontramos uma situação que permitisse a exploração do trabalho agrícola sem o emprego de sistemas de repressão de mão-de-obra.

Ao contrário, existiam terras livres próximas a Campos, passíveis de ocupação, mesmo não legal, que se transformavam em chamariz para uma população liberta do domínio dos grandes produtores, onde o trabalhador, principalmente o ex-escravo, poderia produzir para si próprio, sem ter 'patrão' nem 'senhor' (FARIA, 1986: 288).

Mais uma vez a fronteira agrícola aberta é identificada como um fator de entrave para a apropriação capitalista de sobretrabalho. E se num primeiro momento, os colonos - dada a necessidade premente de mão-de-obra - conseguem obter algumas regalias junto aos proprietários, a estabilização da situação, na primeira década do século XX, demonstrava como os contratos seriam cada vez mais vantajosos para os senhores. O colono passava a plantar com financiamento do proprietário, utilizando-se de ferramentas alugadas; o transporte ficava a cargo do senhor, e relações próximas ao sistema de "barracão" (monopólio do proprietário sobre a venda de mantimentos aos colonos) fracionavam a independência do produtor. Enfim, os senhores rurais de Campos, assim como de outras localidades que viveram processo análogo, souberam preservar sua condição de classe lançando mão da extração de sobretrabalho do lavrador nacional, prescindindo, portanto, da imigração como condição de sua sobrevivência (FARIA, 1986: 302-303).

\subsection{Dispersão de mão-de-obra para além da fronteira: caipirização}

Por fim, também no exemplo enquadrado em nosso quarto modelo, a perda de autonomia do produtor direto consistiu em característica da transição do trabalho escravo para o livre. No entanto, pela natureza da estrutura agrária de Capivary, alguns dados devem agregar-se, relativizando seus efeitos sobre a formação de trabalhadores rurais aptos a serem explorados por proprietários de meios de produção. A relativa independência desfrutada através da propriedade de escravos - ainda que em pequeno número, e de cativos de menor valor -, da ocupação de terras devolutas ou de parcelas de terras alheias, onde eram erigidas "situaçôes", foi sendo progressivamente minada a partir da década de1870. 
Os situados começaram a perder sua autonomia frente aos senhores de terras na medida em que estes últimos compravam as situações dos primeiros por preços que, podemos conjecturar, poderiam ser menores do que o valor das mesmas. Ou os antigos moradores eram mantidos nas "suas" terras, sob uma nova situação de submissão direta - como agregados, camaradas ou parceiros - ou expulsos e substituídos por novos trabalhadores. Enfim, nos inventários de lavradores da década de 1880, já era bem perceptível o estabelecimento de um vínculo entre situados, situações e proprietários legais da terra. $\mathrm{O}$ caráter consensual que havia na ocupação de terrenos alheios dissolve-se diante da possibilidade de desagregação da economia escravista, e da necessidade de recriação das relações de trabalho no campo (CASTRO, 1985: 236-238).

Terras de antigas fazendas partilhadas e vendidas pelos herdeiros, praticamente abandonadas pelos proprietários, tornam-se agora objetos de litígio com prejuízo para os 'situados' instalados nas mesmas (CASTRO, 1985: 239).

A dissociação entre o fruto do trabalho sobre a terra alheia e a própria terra começava a desvanecer, portanto, na medida em que os proprietários começavam a pressionar os antigos "situados" em seus terrenos a pagarem renda, transformando portanto as relações entre estes atores sociais no espaço rural.

É também ao longo dos anos 1880 que em Capivary veremos um processo de acirramento da diferenciação social entre homens livres no campo. A antiga fração da classe dominante representada pelos senhores rurais (que, pela pequena dimensão de suas posses não poderia ser comparada aos barôes da cafeicultura fluminense, evidentemente), além de praticamente monopolizar o crédito e a mão-de-obra escrava após a abolição do tráfico negreiro, empreende uma estratégia deliberada, segundo Castro, para também monopolizar o acesso à terra a fim de preservar sua posição de classe diante de uma ruptura estrutural representada pelo esgotamento do escravismo (ação esta empreendida, da mesma maneira, por outras fraçôes regionais da classe em questão). Já os homens livres pobres - que tornavam-se cada vez mais o polo de oposição diametral aos grandes proprietários - reagiram no município de maneira análoga a seus congêneres em outras partes: tentaram, contra todas as forças, se estabelecer como pequenos proprietários, manter-se nas terras outrora ocupadas e lavradas recorrendo à justiça, aceitaram a submissão à relações de parceria e arrendamento, ou - o que é mais importante - se deslocaram para além da atrativa fronteira agrícola estabelecida, almejando escaparem à extração de sobretrabalho e garantirem a liberdade e propriedade integral do fruto de seu labor (CASTRO, 1985: 241-243).

Analisando os reflexos desta situação nas primeiras décadas do século XX, Castro lança mão de entrevistas realizadas com habitantes rurais do município de Silva Jardim (nome atual de Capivary) e dos dados fornecidos pelo Censo de 1920. Vemos através dos dados arrolados que as unidades agrícolas - tendo passado por um acirrado processo de fracionamento ao fim do século XIX, configurando a região como uma área de pequenas propriedades -, fossem elas exploradas por meio de parceria, aforamento ou através de outras formas de posse -, continuavam a ser exploradas por meio de práticas agrícolas rudimentares, assinalando a mesma estagnação técnica verificada na maior parte dos municípios estudados. As relações de arrendamento foram raras em Capivary, não sendo analisado nos recenseamentos nenhum estabelecimento rural nesta situação. As culturas de alimentos continuavam sendo predominantes, principalmente a mandioca (com a produção de farinha), milho, arroz e feijāo, realizadas por meio de queimadas como meio de fertilização do solo e do uso de instrumentos como machados, foices e enxadas. O café ganhava espaço onde era possível seu cultivo, mas para resultados mais modestos que os anteriormente obtidos: um dos índices de empobrecimento da região, e em especial das produções cafeeiras reside na perda de importância do processamento do produto e da maior participação da venda de café em coco. Não se tratando de mera produção de subsistência, efetuava-se inserção mercantil estabelecida por meio da comercialização do excedente com atacadistas sediados na área urbana do município (CASTRO, 1985: 263-264).

O trabalho familiar, ao que tudo indica, foi a forma hegemônica de exploração das unidades produtivas em Capivary com o fim da escravidão, o que não excluiu o emprego de outras formas de trabalho adicional circunstanciais. Pôde-se concluir que o emprego de trabalhadores diaristas não foi excep- 
cional, segundo a autora, principalmente nos primeiros anos após a Abolição. Segundo alguns relatos, a apropriação de sobretrabalho foi mantida, mesmo em propriedades de pequeno porte, com menos de 50 ha, por meio do trabalho de lavradores agregados (de fazendas vizinhas ou estabelecidos nas próprias terras do contratante) a partir do pagamento de salários, que deveriam girar em torno de $\$ 800$ a $2 \$ 000$ diários, logo após 1888. Ou ainda, segundo entrevista analisada, 30\$000 mensais além das refeições, pagos a ex-escravos de um proprietário (CASTRO, 1985: 265).

Afirma a autora, no entanto, que a solução buscada no assalariamento foi momentânea, tendo poucas possibilidades de manutenção:

A condição de produtores voltados para subsistência dos trabalhadores a jornal, ainda sem qualquer vínculo legal com o proprietário da terra, faziam-los mão-de-obra instável para responder sozinha pela continuidade da produção comercial (CASTRO, 1985: 266).

Isto porque "Em todos os casos analisados (...) o dinheiro recebido a jornal era remuneração eventual e complementar às roças de subsistência cultivadas.” (CASTRO, 1985: 267). Prova disso está na mudança efetuada pelos proprietários do emprego de trabalhadores diaristas para o estabelecimento de parcerias, de maior estabilidade: a necessidade de controle sobre a mão-de-obra (compreensível, dada a pressão exercida pelas terras livres) levava, inclusive, os proprietários a exigirem trabalho gratuito dos agregados com roças de subsistência em suas terras, tamanha a dificuldade em compelir-lhes ao trabalho para outrem.

Vale lembrar, no entanto, que somente nas áreas em que as produçōes agrícolas continuaram a ser empreendidas sob direção do proprietário é que a autonomia dos ditos "situados" foi demolida. A possibilidade de estabelecimento, por parte dos pequenos lavradores, em terrenos livres, dificultava a preservação da condição de classe dos grandes proprietários.

a clara estratégia detectada a partir do último quartel do século XIX de transformar a 'pobreza local' em força de trabalho (...) não representou a manutenção dos significados políticos e sociais da antiga hierarquização (CASTRO, 1985: 270).

A migração de capitais para fora do município e o crescimento demográfico, entre as décadas de 1870 e 1890, basicamente proporcionado pelo afluxo de negros e mestiços, demonstrou como Capivary configurou-se, na crise do escravismo, como "polo de atração de parte da população liberta da província, a partir da abundância de terras livres que caracterizava a organização fundiária local' (CASTRO, 1985: 275), palco de um processo de "capirização", com a predominância do trabalho familiar, baixa capitalização, técnicas rudimentares, fragmentação da propriedade da terra, produção de subsistência e relativa estabilidade do produtor independente, contrastando com as condições impostas aos agregados nas "fazendas" restantes.

\subsection{Contradições do Modelo "fronteira agrícola fechada e concentração fundiária"}

Motta insistiu que uma das características mais marcantes dos sistemas agrários em Niterói consistia na formação de uma fronteira fechada em função da concentração da propriedade fundiária, da existência de terras não-agricultáveis em $50 \%$ da região e do incentivo às atividades mercantis proporcionado pelos mercados da cidade de Niterói e do Rio de Janeiro. Tal situação teria possibilitado o emprego de exploração intensiva na agricultura de alimentos e proporcionado abundância de mão-de-obra.

Até 1850 teria sido possível em Niterói o estabelecimento de pequenos proprietários por meio do arrendamento, o que lhes conferiria uma determinada estabilidade. No entanto, a crise decorrente do fim do tráfico negreiro e a absolutização da propriedade por meio da Lei de Terras teria abalado esta situação, elevando o valor das rendas e dificultando o acesso ao cativo por parte dos pequenos lavradores. Como o acesso se dava exclusivamente pelo arrendamento - visto o valor das terras em Niterói e a "fronteira fechada" - os agricultores precisaram se tornar mais competitivos que seus concorrentes para conseguirem melhores mercados e recursos para pagarem maiores rendas. Neste cenário darwinista, a diferenciação social 
entre o campesinato niteroiense iria acirrar-se, conduzindo à perda de estabilidade e consequente proletarização de uma parcela substancial dos antigos arrendatários, enquanto os sobreviventes - proprietários mais abastados - passariam a explorar com tranquilidade a mão-de-obra abundante, sem acesso à terra.

Este quadro de transição empalidece diante da seguinte pergunta: foi a fronteira agrícola no município de Niterói realmente fechada? Na medida em que Motta demonstra a acumulação de capital a partir do arrendamento como uma prática comum e segura de investimento no município - tendo oferecido dados convincentes - estamos diante de um indício da existência de uma oferta de terras sob efetivo controle da classe proprietária, o que limitaria as possibilidades de reprodução autônoma do trabalhador por meio da posse. Mesmo que admitamos que não existissem terras devolutas em Niterói, e que portanto, sua fronteira agrícola estivesse realmente fechada, em que medida o município estaria isolado da pressão exercida por áreas muito próximas, nas quais as terras disponíveis fossem um chamariz para a população liberta e imigrante que desejasse fugir da exploração do trabalho, cujos exemplos abundam dentre os analisados neste estudo?

Motta apresenta um quadro semelhante ao proposto por Ellen M. Wood (WOOD, 2001) para a origem do capitalismo inglês. A absolutização da propriedade da terra teria conduzido ao aumento de seu valor, e portanto, do valor dos arrendamentos. Tal fato colocaria os arrendatários diante do dilema "modernizar ou abandonar a terra", gerando neste processo agricultores modernos (os que sobrevivem) e proletários (os que abandonam). A aceitação desta interpretação para o município de Niterói requer que subestimemos a capacidade dos lavradores de fugirem para áreas de fronteira ou para os centros urbanos em desenvolvimento. A proletarização do trabalhador deve estar ligada ao imperativo da sobrevivência - como nos lembra Wood -, à completa submissão da subsistência ao capital. Este não parece ser o caso, visto a existência de uma fronteira agrícola aberta, possivelmente não em Niterói, mas nos municípios circunvizinhos.

Motta alega que a perda de autonomia dos lavradores sem-terra teria criado inevitavelmente um exército de reserva satisfatório para os interesses das fazendas. Mesmo assim, é com certo espanto que aponta o fato de que, ainda em 1910, preservava-se o discurso, por parte dos fazendeiros, acerca da "falta de braços" para a lavoura. Mas ao mesmo tempo, estes fazendeiros desfrutariam de uma situação privilegiada que os assegurava o pagamento de salários baixíssimos:

O discurso da raridade de trabalhadores encobria uma realidade onde o trabalhador rural ganhava de dois mil e quinhentos réis 'a seco' ou de um mil e quinhentos a dois mil e quinhentos réis 'com comida' por diária. Não era muito, na verdade era perto do nada (MOTTA, 1989: 169).

Em comparação com salários pagos na cidade do Rio de Janeiro a trabalhadores braçais do setor de construção civil, os jornais oferecidos aos lavradores na década de 1910 seriam muito inferiores (cerca de quatro a cinco vezes menores). Com isto, Motta afirma que a Capital Federal funcionou como um polo de atração desta mão-de-obra. "Se parte desta população optou pelo trabalho urbano foi porque este se constituia numa saída frente a opressão representada pelos proprietários de terras." (MOTTA, 1989: 171).

Para compararmos salários urbanos e rurais, seria preciso que estivéssemos lidando com dois tipos de relações de produção semelhantes; caso contrário, as conclusões poderiam ser falseadas pelas aparências. Se assumirmos a proletarização do trabalhador rural em Niterói, fica compreensível a argumentação da autora: salários baixíssimos, comparados aos urbanos, levavam ao abandono das fazendas, e a reclamação dos fazendeiros a respeito da falta de mão-de-obra seria falsa, somente escondendo uma realidade dura vivida pelos operários rurais. Mas, tendo em vista que Motta não menciona que tipo de relaçôes de trabalho se instauram no campo em Niterói pós-1888, limitando-se a falar do valor dos salários pagos, fica a dúvida acerca dos termos contrapostos. ${ }^{5}$

Em sua tese de doutorado, a autora criticaria a aceitação dos diagnósticos sobre as terras devolutas feitos no século XIX, demonstrando que as avaliaçôes foram, via de regra, falseadas pelos responsáveis locais, sob influência dos latifundiários, com o objetivo de abrirem espaço para a apropriação ilegal de 
terras públicas, alegando ser a maior parte destas terras propriedade privada (MOTTA, 1998). Em sua dissertação de mestrado, no entanto, Motta aceitou o discurso oficial para comprovar a existência de uma "fronteira fechada" em Niterói:

Em primeiro lugar, inexiste qualquer referência a terras devolutas. Informaçōes do tipo 'terras devolutas' ou 'em terras a que de direito pertencer' são simplesmente ausentes nos registros, contrastando com os referentes à regiōes de fronteira aberta (como exemplo, Angra dos Reis) (...) Em segundo lugar, não existem terras tomadas por posse (MOTTA, 1998: 111).

Além disso, mesmo que a fronteira fosse realmente fechada, não considera as migrações, como o fez Monteiro:

Geralmente os migrantes provém de regiōes com problemas de ordem econômica, somados à seca no Nordeste, como foi o caso da crise da economia nordestina (...) Regiōes conhecidas como aquelas que perdem população são o Nordeste, Minas Gerais e o interior do Estado do Rio de Janeiro. Como aquelas que recebem população encontramos a Amazônia, na época do surto da borracha, o Estado de São Paulo e a cidade do Rio de Janeiro, se bem que se observa estarem ocorrendo migrações em todos os sentidos e direções (...) De qualquer forma, destaca-se o fato de que as migrações internas, nesse período, foram mais no sentido rural-rural do que na direção rural-urbana, com uma única exceção, o caso do Rio de Janeiro (MONTEIRO: 1990: 218).

O fenômeno de atração de mão-de-obra do campo pelas cidades foi uma marca do capitalismo inglês. No entanto, neste exemplo, ocorrera uma revolução agrícola que, com novas técnicas e relações de trabalho, dera sustentação ao desenvolvimento urbano através de uma agricultura capitalista. Esta não foi um das marcas do processo de eliminação do escravismo e de afirmação do trabalho livre no Brasil: a dispersão de mão-de-obra para a cidade do Rio de Janeiro, juntamente com a pressão exercida pela fronteira agrícola aberta, criaram um ambiente propício à repressão ou imobilização da mão-de-obra como condição de preservação da grande propriedade.

A construção de um suposto "mercado de trabalho abundante" para as fazendas em Niterói, acompanhada da reclamação a respeito da falta de braços e dos salários baixos poderia engendrar uma contradição se estivéssemos lidando com uma agricultura baseada em relações de produção capitalistas. Não sendo o caso, podemos reavaliar os dados fornecidos por Motta: a) os baixos salários são indício de outras formas de provimento da subsistência por parte dos trabalhadores, que não dependem da remuneração monetária para reprodução enquanto mão-de-obra; b) a reclamação dos fazendeiros é demonstração real da pressão exercida pela cidade e pela fronteira aberta, não sendo, como alega a autora, "falsidade", c) a mencionada "opressão dos proprietários", responsável pela fuga dos lavradores para a cidade, é indício do uso de expedientes violentos na imobilização da mão-de-obra no campo, dada a pressão da fronteira aberta. Martins esclarece mais a este respeito:

Por outro lado, é claro também que o colono recebia pagamentos em dinheiro pelo café entregue ao fazendeiro. Mas esses pagamentos estavam muito aquém dos salários urbanos. O que um operário ganhava em um mês era geralmente o que o colono recebia em um ano para cuidar de mil pés de café. É certo, porém que havia outros rendimentos monetários para o colono, pois em geral podia cuidar de 2000 pés de café, além dos ganhos proporcionais à colheita (MARTINS, 1979: 84).

\subsection{Insuficiência da hipótese da "terra cativa"}

Fragoso assume que o "cativeiro da terra", ou seja, o condicionamento do acesso à terra a compra, fora suficiente para criar um contingente de trabalho livre, privado do acesso aos meios de produção, ainda que não composto de "proletários", como afirma Motta. Isto porque foi através da reafirmação do caráter pré-capitalista das relações de trabalho que se efetuara a transição do escravismo. Nos casos em que o trabalhador obteve acesso à terra a partir da troca por trabalho excedente (colonato, meação, etc.) realmente teríamos mão-de-obra pré-capitalista formada pelo controle do acesso à terra pelo proprietário, estando 
configurado um exemplo de como a propriedade fundiária dos senhores engendrara uma lógica de submissão do produtor direto. No entanto, temos visto até aqui que o suposto fechamento de fronteiras ocasionado pela Lei de Terras não fora suficiente para evitar a expansão - ilegal - dos pequenos posseiros nem conter a mobilização da mão-de-obra através do território, migrando para áreas abertas.

Tal fator nos leva a crer, portanto, que ao contrário do defendido pelo autor, o mero monopólio da terra e sua mercantilização não foram expedientes suficientes para a conformação de relações de produção livres, ainda que não baseadas no assalariamento. Motta estudou em sua tese de doutoramento (MOTTA, 1998) os conflitos entre posseiros e senhores pelo controle de regiōes de fronteira, e dela inferimos que foi através da violência de classe que se edificou a ordem rural após 1850 e 1888 . Foi necessária sobretudo a ação direta dos proprietários, através dos mais variados meios, para a manutenção da mão-de-obra nas grandes propriedades e para a extração de sobretrabalho, ameaçada pela possibilidade de dispersão para áreas de fronteira. Dada a ineficácia da Lei de Terras no que tange impossibilitar a formação de uma economia camponesa livre periférica, o "cativeiro da terra" não foi um mecanismo suficiente para a preservação dos elementos básicos da estrutura agrária anterior a 1888.

Uma agricultura dependente de terras virgens e da ação predatória, tendência manifesta desde os tempos coloniais e que se reproduzira ao longo dos séculos XIX e XX engendrava uma dupla pressão: a) uma, para abandono dos postos de trabalho e formação de uma economia camponesa por parte dos trabalhadores; b) outra, para a apropriação destas regiões de fronteira pelo latifúndio, levando ao conflito social. A Lei de Terras foi apropriada de modo diferenciado pelos dois lados, e utilizada como arma de legitimação das posições de latifundiários e pequenos posseiros. Assim, a existência deste instrumento jurídico não possibilitou a cristalização da estrutura fundiária; ela foi resultado das décadas de violência entre proprietários e expropriados. A falta de condições sociais e estabilidade institucional para a regularização da propriedade de terras ocupadas por posseiros impossibilitou a formação de uma moderna agricultura camponesa independente. Era, portanto, o poder da aristocracia rural e do grande capital que conformava a "via prussiana" de manutenção da grande propriedade.

A exploração de sobretrabalho, numa situação de fronteira agrícola aberta e de atratividade das cidades necessitava da fixação do homem à terra em condições menos arriscadas que aquelas obtidas numa vida no wilderness, com a possibilidade de ser expulso pelos grandes "proprietários" de direito ou não, e de ser vítima da violência rural empreendida por bandos armados por latifundiários. Em outras palavras, explorar mão-de-obra sob estas condiçōes exigiu expedientes como concessão de parcelas de terra, participação nos rendimentos da lavoura do proprietário, ou outros métodos de coerção sobre a mãode-obra, tais como dívidas, ameaça física ou perda de "proteção".

De qualquer forma, fosse concedendo "vantagens" ao trabalhador - que não eram benefícios reais, mas a garantia de ser não ser morto ou levado a tribunal por posse ilegal (MOTTA, 1998: 76) - ou ameaçando-o física e psicologicamente, garantiu-se os braços para a lavoura. O emprego do proletário rural, que aceita submeter-se ao capital pela total falta de meios de sobrevivência a não ser a venda livre de sua força de trabalho, seria muito difícil nestas condições.

Fragoso também se contradiz a este respeito: assume a eficácia da Lei de Terras como conformadora de uma fronteira fechada e aceita os diagnósticos oficiais sobre as terras devolutas, justificando o cativeiro "jurídico" da terra pela baixa relação entre homens e terras, única forma portanto de obtenção de mão-de-obra e sobretrabalho. Isso não explica, entretanto, as razões da permanência de modos de produção não-capitalistas, uma vez que a situação descrita faria crer existirem, abstraindo-nos de outros fatores, condições ideais para o surgimento do capitalismo rural (impossibilidade de formação de lavradores autônomos, monopólio real da terra, controle efetivo por parte do Estado classista para a preservação do direito de propriedade) (FRAGOSO, 1983: 135).

Afirma que a configuração de relações não-capitalistas ocorre num contexto de carência de mãode-obra, demonstrado pela diminuição da população e pela ausência de fluxo migratório. Citando relatos de época, demonstra a percepção de uma situação semelhante àquela descrita por Motta para Nite- 
rói. Os proprietários queixavam-se das dificuldades de prosseguirem suas atividades em função de uma contínua falta de braços. Nestes termos, a inexistência de um mercado de trabalho ou de um "exército de reserva" apto a ser recrutado na região elevaria os salários: "caso a mão-de-obra fosse assalariada stritosensu isso acarretaria o encarecimento de seu custo." (FRAGOSO, 1983: 139). Fragoso é coerente aqui em reconhecer a especificidade das relaçóes de trabalho livre em Paraíba do Sul.

Prossegue afirmando que, uma vez não tendo sido a abolição da escravatura acompanhada do desenvolvimento das forças produtivas, perpetuando-se as técnicas tradicionais, não criar-se-ia um ambiente favorável ao emprego do trabalhador assalariado: como a produtividade do trabalho e a relação entre trabalho necessário e trabalho excedente teriam se preservado, uma transformação rumo ao capitalismo implicaria o aumento do tempo de trabalho necessário, reduzindo assim a margem de sobretrabalho apropriado pelo proprietário.

"Deste modo, a configuração das relações de produção pós-escravidão na agricultura de exportação de Paraíba do Sul, o seu caráter não capitalista, deve-se ao nível das forças produtivas presentes na regiāo." (FRAGOSO, 1983: 140).

\section{Dispersão de mão-de-obra x Coerção ao trabalho}

Julgamos apressado atrelar a questão da não-implementação do capitalismo rural no período estudado à questão das forças produtivas simplesmente. A pressão sobre o trabalho exercida por uma fronteira agrícola aberta é um fator indiscutível para a persistência de regimes de exploração baseados em coação "extraeconômica". Se a terra é "cativada" por meio da Lei de Terras, impedindo seu acesso a não ser pela compra, atestado que ao fim do século XIX já não existiam terras devolutas na região ${ }^{6}$ e comprovada a carência de braços, para onde teriam ido os trabalhadores, além da Capital Federal e outros centros urbanos? Mais ainda, se havia a necessidade do emprego de coerção não-econômica para a fixação do trabalhador à terra - há de se convir que na mesma medida - a ameaça (corrente ou possível) de estabelecimento de uma agricultura camponesa na fronteira era real. Mas como, se as fronteiras agrícolas estavam juridicamente fechadas? A eficácia da Lei de Terras não fora suficiente para resolver, pela sua simples aplicação, os problemas de mão-de-obra. E mesmo que em Paraíba do Sul não mais existissem terras devolutas, o que dizer a respeito dos municípios e estados vizinhos, em outras condições?

O capitalismo rural no sudeste brasileiro e em muitas outras localidades não foi somente inviabilizado por uma questão técnica ou por um projeto hegemônico da classe proprietária, mas também pela pressão da fronteira agrícola em favor da dispersão da mão-de-obra. Elisa Reis e Eustáquio Reis sugeriram inclusive que estes mesmos projetos de hegemonia por parte das elites agrárias do Sul foram moldados a partir da fronteira agrícola aberta, assumida como um condicionante sobre o comportamento e expectativas deste grupo (REIS e REIS, 1988). A elite latifundiária, para a preservação da sua hegemonia enquanto classe proprietária na crise do escravismo, recusou-se a ceder espaço à transformação com base na via farmer, a sofrer a concorrência de pequenos produtores capitalistas modernos e a perder mão-de-obra. Preservou portanto sua condição de classe por meio de comportamentos que contribuíram para a associação entre uma economia urbano-industrial e sistemas repressivos de mão-de-obra no campo, que limitaram a mobilidade do trabalhador, preservaram a grande propriedade e coagiram ao trabalho expropriado. A existência de uma extensa fronteira agrícola aberta em disputa - como em Paraíba do Sul e Campos - e as inúmeras possibilidades de estabelecimento de pequenas propriedades - como no caso de Capivary - conduziram a uma situação que torna discutível a existência de um sistema agrário com "fronteiras fechadas" e concentração de propriedade, tal como proposto por Motta para Niterói. As condiçôes estruturais em favor da dispersão de mão-de-obra criaram o cabo-de-guerra entre a repressão ao trabalhador e o estabelecimento de posseiros em terras desocupadas, configurando um importante aspecto da modernização conservadora no Brasil. 


\section{Notas}

\footnotetext{
${ }^{1}$ A autora faz questão de lembrar que não se trata em nenhum momento da afirmação de que na região de Niterói, no século XIX, constituía-se uma estrutura agrária de fronteira fechada como no modo de produção capitalista, ou seja, com a concentração de terras no processo produtivo ou meramente como reserva de valor. É o caráter de ocupação antiga que determina a concentração fundiária, não a apropriação capitalista da mesma.

${ }^{2}$ Ao menos é desta maneira que apresenta Motta. Apresentaremos argumentos que pretendem relativizar a tese da "fronteira fechada" em Niterói, sugerindo que a impossibilidade de controle sobre a dispersão da mão-de-obra foi um importante fator para o emprego de coação extraeconômica sobre a força de trabalho na agricultura brasileira em diversas partes do País.

${ }^{3}$ Ainda que na região, como lembra a autora, não tenham existido latifúndios nas mesmas dimensões que os existentes em regiōes agroexportadoras de grande dinamismo, como Paraíba do Sul.

${ }^{4}$ Martins também apontara que, no regime de colonato, vigente na agricultura paulista, os trabalhadores familiares forneciam alimentos para a fazenda, demonstrando o papel da produção de subsistência com inserção mercantil na estrutura socioeconômica rural (MARTINS, 1979: 83).

${ }^{5}$ Compreendemos que os marcos cronológicos que a autora propõe-se a analisar circunscrevem-se ao período de 1808 a 1888.

6 "Em 1898, não existiam terras devolutas em Paraíba do Sul”(FRAGOSO, 1938: 137).
}

\section{Referências Bibliográficas}

BARREIROS, Daniel de Pinho. Modernização conservadora no Brasil: Estado e classes sociais na construção da "via prussiana" de transição para o capitalismo (1880-1890). Dissertação de Mestrado apresentada ao Programa de PósGraduação em História Social da UFF. Niterói, 2002.

CASTRO, Hebe M. da Costa Gomes de. À margem da História: homens livres pobres e pequena produção na crise do trabalho escravo. Dissertação de Mestrado apresentada ao Programa de Pós-Graduação em História Social da UFF. Niterói, 1985.

FARIA, Sheila Siqueira de Castro. Terra e trabalho em Campos dos Goitacases (1850-1920). Dissertação de Mestrado apresentada ao Programa de Pós-Graduação em História Social da UFF. Niterói, 1986.

FRAGOSO, João Luis Ribeiro. Sistemas agrários em Paraíba do Sul (1850-1920): um estudo de relaçôes não-capitalistas de produção. Dissertação de Mestrado apresentada ao Programa de Pós-Graduação em História da UFRJ. Rio de Janeiro, 1983.

MARTINS, José de Souza. O Cativeiro da terra. São Paulo: Ciências Humanas. 1979.

MOORE Jr., Barrington. As origens sociais da ditadura e da democracia: senhores e camponeses na construção do mundo moderno. São Paulo: Martins Fontes, 1983.

MONTEIRO, Hamilton de Mattos. "O aprofundamento do regionalismo e a crise do modelo liberal". In: LINHARES, Maria Yedda (org). História geral do Brasil. Rio de Janeiro: Campus, 1990, pp. 211-228.

MOTTA, Márcia Maria Menendes. Pelas "Bandas d'Além": fronteira fechada e arrendatários escravistas em uma regiāo policultora (1808-1888). Dissertação de Mestrado apresentada ao Programa de Pós-Graduação em História Social da UFF. Niterói, 1989.

. Nas fronteiras do poder: conflito e direito à terra no Brasil do século XIX. Rio de Janeiro: Vício de Leitura / Aperj, 1998.

REIS, Eustáquio J.; REIS, Elisa P. “As elites agrárias e a abolição da escravidão no Brasil”. Dados, vol. 31, no 3, pp. 309-341, 1988.

SAMPAIO, Antônio Carlos Jucá de. Magé na crise do escravismo: sistema agrário e evolução econômica na produção de alimentos (1850-1888). Dissertação de Mestrado apresentada ao Programa de Pós-Graduação em História Social da UFF. Niterói, 1994.

WOOD, Ellen Meiksins. A origem do capitalismo. Rio de Janeiro: Jorge Zahar Editor, 2001. 


\title{
RESUMO
}

Com base no conceito de "via prussiana" defendido por Barrington Moore Jr., o artigo retoma importantes teses no estudo dos sistemas agrários fuminenses, na conjuntura de crise do trabalho escravo e de transição para o trabalho livre, argumentando que a ideia de uma "fronteira agricola fechada" a partir da Lei de Terras é insuficiente para definir as relações de trabalho e de acesso à terra estabelecidas após 1888. As conclusóes destas teses, quando analisadas em conjunto, nos permitem afirmar que a existência de terras livres exerceu forte pressão contrária aos mecanismos de "proletarização" do trabalhador rural, levando portanto ao emprego de "sistemas repressivos de mão-de-obra" como alternativa viável de preservação da grande propriedade, configurando assim um aspecto fundamental da modernização conservadora, tal como previsto por Moore Jr. Palavras-chave: via prussiana, modernização conservadora, trabalho escravo, sistemas agrários, questão agrária.

\begin{abstract}
Assuming the concept of "prussian way" defended by Barrington Moore Jr., this article retakes some important theses on the study of the agrarian systems in Rio de Janeiro, in the context of the crisis of slave labor and transition to free labor in the second half of the $19^{\text {th }}$ century. The main argument of this work is centered upon the failure of the Land Law of 1850 in creating an effective closed agricultural frontier. Henceforth, we support that the pressure exerted by de facto free lands is crucial to the nature of labor relations after 1888. The conclusions of the studied theses, when analyzed as a whole, enables us to affirm that the existence of free lands wielded hard pressure against proletarization mechanisms acting over rural workers, and so leading to the use of "repressive labor systems" as a viable alternative to the survival of the large estate, revealing itself as a fundamental aspect of the conservative modernization, as conceived by Moore Jr. Keywords: prussian way, conservative modernization, slave labor, agrarian systems, agrarian question.
\end{abstract}

